\title{
MODERN BURNER FOR CENTRAL HEATING BOILERS UTILIZING RENEWABLE ENERGY SOURCE - BIOMASS
}

\author{
Tomasz Huscio $^{1}$, Albert Kowalewski ${ }^{2}$ \\ ${ }^{1}$ Bialystok University of Technology, Poland; ${ }^{2}$ Pionier Elektryk, Poland \\ t.huscio@pb.edu.pl, ${ }^{2}$ biuro@pionier-elektryk.pl
}

\begin{abstract}
To meet the technological requirements concerning the efficiency of using the energy of fuel in biomass furnaces and the profitability of implementing new solutions, it is necessary to continuously modify and optimize the existing biomass heating systems. Boiler designs with modern biomass-fueled burners should be characterized by high energy and environmental efficiency. The amount of the heat obtained indicates the efficiency of the burning process. The quality of the burning process can be evaluated by means of the efficiency of the equipment that burns fuel. The higher the efficiency, the more energy is obtained from burning a unit of fuel. Inadequate technological solutions of heating systems result in elevated emissions of harmful substances into the atmosphere and reduction of the efficiency of the combustion process, which generates additional costs of using such systems. However, in this case, one must remember that, besides modern burner designs, minimization of environmental risks also necessitates selection of fuel of the proper quality and a properly selected flue gas exhaust system. This article presents the results of research and development work oriented towards designing and development of a modern, innovative burner for central heating boilers that will ensure high quality of the process of burning pelletized biomass fuels. The scope of pre-implementation research and development work covered: development of a burner design, performance of tests on the burner prototype, development of a control system - burner automation and preparation, and filing of a patent application for the burner.
\end{abstract}

Keywords: central heating boiler, burner for central heating boilers, renewable energy, biomass, air pollutant, smog.

\section{Introduction}

Pollution of the natural environment concerns air, soil and water. Air quality is of decisive significance in the process of environmental pollution. Primary pollution introduced into the atmosphere (Carbon dioxide $\left(\mathrm{CO}_{2}\right)$, Carbon monoxide $(\mathrm{CO})$, Nitrogen oxides $\left(\mathrm{NO}_{\mathrm{x}}\right)$, Sulphur dioxide $\left(\mathrm{SO}_{2}\right)$, total suspended particulates (TSP) as well as particulate matter $\mathrm{PM}_{10}, \mathrm{PM}_{2.5}$, etc.) generate chemical compounds that have a destructive impact on other elements of the natural environment soil and water. Air pollution is mobile, and because of this, under specific weather conditions, large areas of practically all components of the environment can be contaminated very quickly.

Numerous articles and reports concerning air pollution in Europe and its harmful impact on human health and the environment can be found on the website of the European Environment Agency (EEA) [1-6].

The interactive map of the pollution level around the world [7] can be used to check the value of the Air Quality Index (AQI) in individual cities around the world as well as the health implications corresponding pollution levels.

According to the data from the WHO, air pollution causes 6.5 million human deaths worldwide. Detailed data concerning the effects of air pollution on health can be found in reports and publications available on the World Health Organization's (WHO) website [8-10].

In response to threats posed by air pollution, the European Union has undertaken legislative actions $[11 ; 12]$. The proposals put forward by the European Commission in the Clean Air Policy Package for Europe seem to be particularly promising. The goals laid down in this document concern achievement of full compliance with the existing legislation by 2020 as well as further improvement of air quality in Europe by 2030 and thereafter [11].

The primary source of anthropogenic pollution emissions are fuel burning processes for energy purposes, particularly those involving coal. Over $75 \%$ of $\mathrm{NOx}$ and $\mathrm{SO}_{2}$ emissions, approx. $70 \%$ of $\mathrm{CO}$ emissions, over $75 \%$ of particulate emissions and over $90 \%$ of $\mathrm{CO}_{2}$ emissions are generated by fuel burning processes [13].

The studies conducted in Poland show that over half of solid particles and over $90 \%$ of benzopyrene originate from the chimneys of household furnaces (e.g., there are nearly 30 thousand such chimneys in the center of Kraków). Other sources of pollution are: street traffic, industrial plants 
and thermoelectric power plants [14]. This is due to the fact that the energy efficiency of installations burning solid fuel, particularly those based on outdated, traditional designs, is low and does not exceed $50 \%$ on an average annual basis. This causes excessive consumption of coal, wood and biomass. This consumption is greater than the demand for useful energy in apartments, single-family homes and public buildings. Moreover, in incomplete burning processes, organic and non-organic carbon-graphite compounds, ash and soot particles, which are harmful to health, are formed.

High toxicant emissions cause a high concentration of air pollution at the near-ground level, particularly in densely populated areas due to the low height of chimneys used in the residential construction sector (so-called low emissions). The coincidence of weather conditions fostering concentration of pollution (e.g., no wind, fog) causes smog to form, which contains sulfur oxide, nitrogen oxides, carbon oxides, soot and particulate matter, all harmful to health. Smog is dangerous due to direct inhalation of polluted air and consumption of food contaminated by it.

Studies of the carcinogenicity of smoke generated by burning coal showed that it is comparable to that of the substances emitted from a coke oven battery and greater than that of cigarette smoke, 2.1; 2.1 and 0.003 , respectively. The emission of dioxins, one of the strongest toxins, increases over 100fold if plastics, rubber, etc. are burned or burned alongside solid fuels in a household furnace or central heating boiler [13].

In 2007, the European Commission started to work on defining the requirements of the Directive 2005/32/EC concerning eco-friendly designing of low-power burning systems - boilers/furnaces /fireplaces fired with solid fuels (coal and biomass). These actions are consistent with the objectives defined in the Green Paper, a European strategy for sustainable, competitive and secure energy and for increasing economic competitiveness [13].

Mandatory, more environmentally friendly furnaces and greater control over the coal that is supplied to the market are the government's proposals for fighting air pollution in Poland. The new regulations under development by the Ministry of Energy and the Ministry of Development would enter into force in 2018 [15].

In relation to this, it is purposeful to design and implement modern burner designs for central heating boilers utilizing a renewable energy source - biomass. These actions should be focused on equipment that will ensure high energy efficiency and environmental protection while being convenient and cheap to use.

\section{Materials and methods}

The goal of the research and development work was to design and conduct pre-implementation tests of a burner for central heating boilers that will ensure high quality of the process of burning pelletized biomass fuels.

The burner for central heating boilers must meet the following conditions.

- Burner type - gasifying tube burner.

- Type of feeder for pelletized biomass - worm screw.

- Fuel - pelletized biomass, i.e. high quality pellets according to the standard [16].

- Type of hot water boiler for which the burner is dedicated - boiler designs that reach the parameters of burning class 3, 4 or 5 according to the standard [17].

- Burner dimensions - width x height x length - $442 \mathrm{~mm}$ x $465 \mathrm{~mm}$ x $840 \mathrm{~mm}$.

- Supply voltage $-230 \mathrm{~V}$.

- Burner power - $15 \mathrm{~kW} ; 25 \mathrm{~kW} ; 35 \mathrm{~kW} ; 60 \mathrm{~kW} ; 100 \mathrm{~kW} ; 150 \mathrm{~kW}$.

- Materials used to make individual covers of the burner chambers:

- gasifying chamber - chamotte insert or heat-resistant sheet, e.g. H24JS,

- mixing chamber - heat-resistant sheet, e.g. H26N4,

- combustion chamber - boiler steel, e.g. P $265 \mathrm{GH}$.

- Emissions of harmful substances - lower than maximum values according to the standard [18].

- The burner automation should enable control of: the fuel feeder, pressure fan, exhaust fan, igniter, boiler temperature, feeder temperature, central heating temperature, hot water 
temperature, external temperature, programmable room temperature, lambda sensor, central heating pump, hot water pump, mixing valve.

- The process of cleaning the gasifying chamber of the burner should be performed automatically at regular time intervals (cyclically).

High volatile content (65-80\%) and the high reactivity of biomass necessitate the application of appropriate designs of combustion systems, central heating boilers/furnaces that would ensure conditions where the volatile products of biomass decomposition, which are emitted in a short time, are completely burned. This is why the boilers designed to burn biomass should essentially have two zones - the degasification zone and the zone for burning products of degasification.

The elements of the designed burner for central heating boilers are presented in Fig. 1.

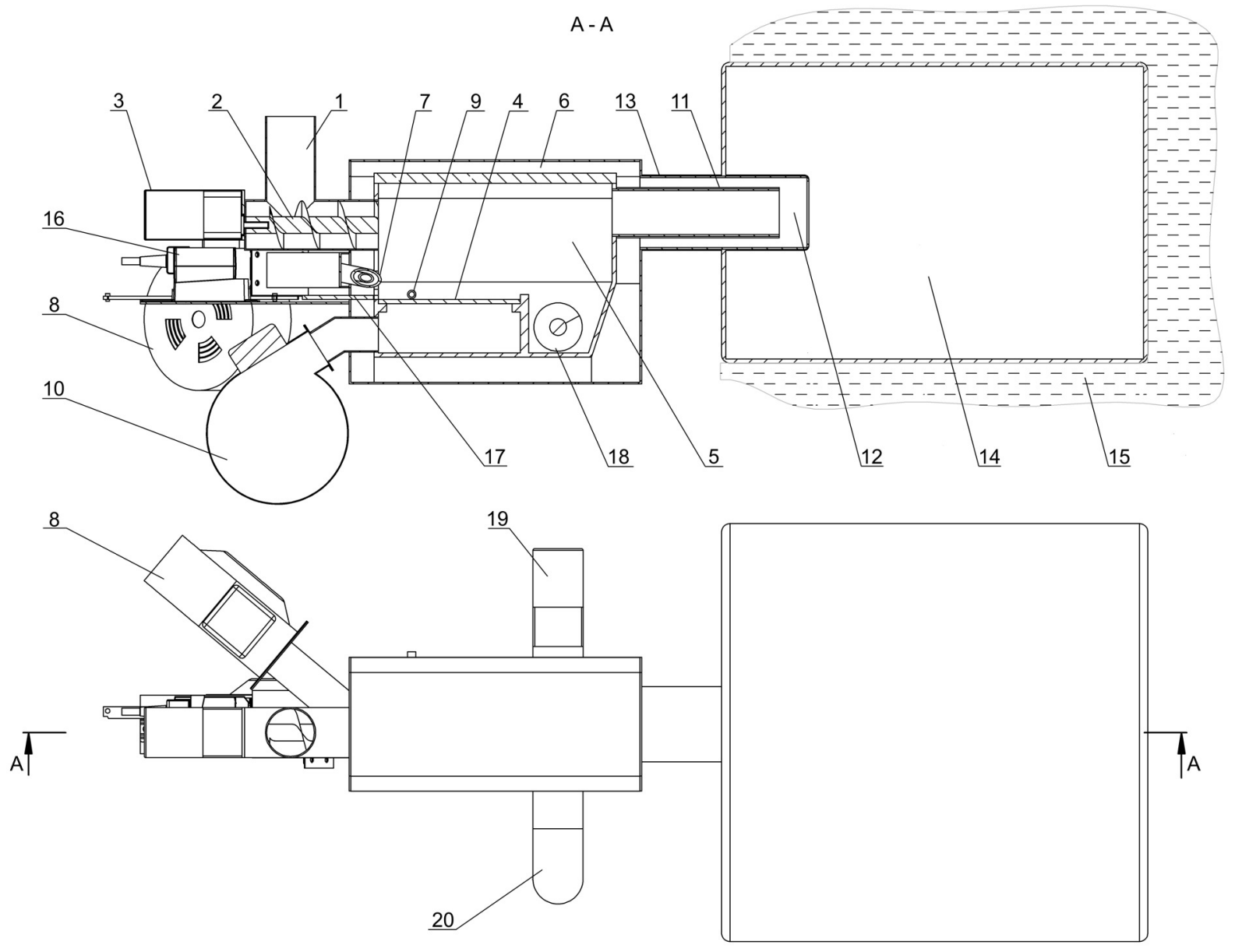

Fig. 1. Basic elements of the designed burner for central heating boilers

Pelletized fuel in the form of biomass is fed to the burner via the fuel inlet (1). The worm screw feeder (2) powered by the motor (3) transports the pelletized biomass onto the grate (4) located in the gasifying chamber (5). The gasifying chamber (5) is found in the air chamber (6). The electrical heater (igniter) (7) with the fan (8), which generates a hot air stream, is used to ignite fuel. The igniter (7) is switched on and off automatically via a controller based on the signal from the flame sensor (9), which detects the presence of flame or lack thereof in the gasifying chamber (5).

The fan (10) draws air from the surroundings, stoking burning of the biomass through the holes found in the grate (4). The gases generated in the gasification process from the gasifying chamber (5) travel through the internal pipe (11) to the mixing chamber (12), where they are mixed with oxygen. Oxygen travels to the mixing chamber (12) along with the air blown in bythe fan (8) via the external pipe (13). Aftercombustion of the gaseous mixture in the mixing chamber (12) creates surplus of oxygen in the combustion chamber (14), which is found in the central heating boiler (15). 
The process of cleaning the grate (4), located in the gasifying chamber (5), is performed automatically at regular time intervals (cyclically) using the controller - drive element system, i.e. the cleanout actuator (16) - cleaning element (17) - worm screw feeder of the ash remover (18). The ash remover worm screw feeder (18), driven by the motor (19), transports ash to the external ash pan (20).

A controller with a lambda sensor measuring the oxygen content in flue gas was applied to control the combustion process. This allows for precise dosage of the fuel-air mixture in individual stages of the biomass combustion process.

Fig. 2 presents the 3D model of the burner developed for central heating boilers. The model was made using SOLIDWORKS software.
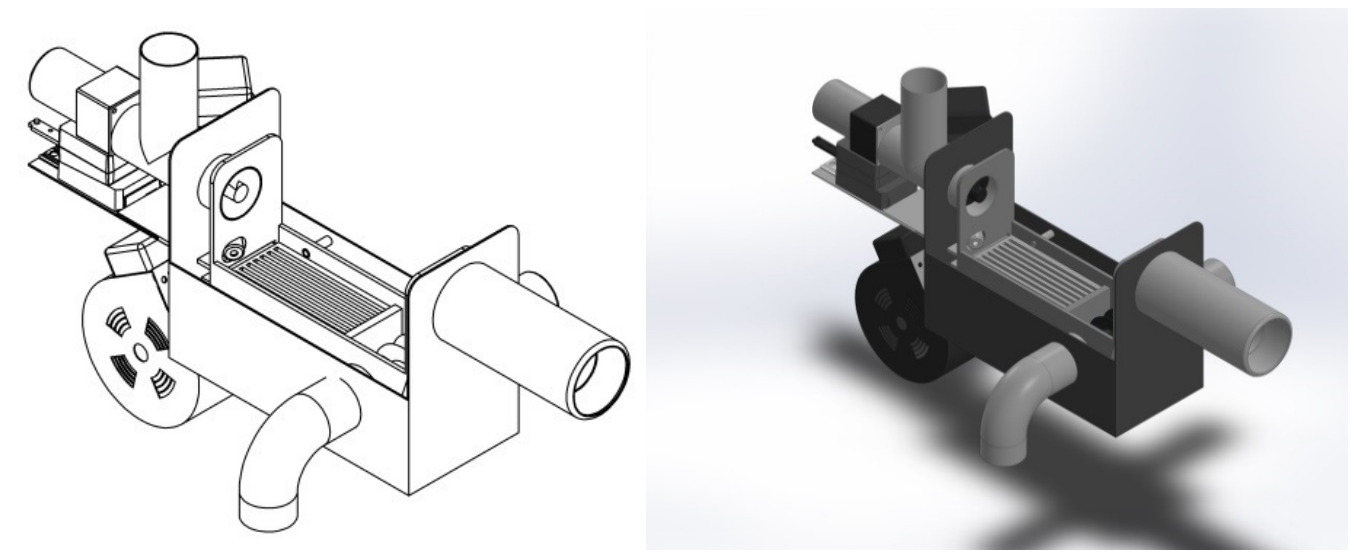

Fig. 2. 3D model of burner for central heating boilers

\section{Results and discussion}

The goal of the tests of the prototype burner was to:

- Check the correctness of operation of the developed burner under real conditions (normal operating conditions);

- Check the quality of burning pelletized biomass fuels;

- Verify assumptions accepted at the burner designing stage.

The developed prototype of the burner for central heating boilers was subjected to the following tests:

- Monitoring of the burner operation, enabling analysis of the biomass combustion system operation under real conditions;

- Measurement of emissions of harmful substances: carbon monoxide (CO), particulate matter.

Measurement of emissions of harmful substances, i.e. carbon monoxide (CO), was performed using an MRU Delta 653 flue gas analyzer. Measurement of particulate matter was performed using the gravimetric method.

The results of the tests of the prototype burner with a power of $25 \mathrm{~kW}$, operating in a boiler, are presented in Table 1 . The burner-boiler combustion system has class 5 flue gas purity according to the standard PN- EN 303-5:2012.

The results of the tests of the prototype burner showed:

- Correct operation of the developed burner under actual conditions (normal operating conditions);

- High quality of burning pelletized biomass fuels;

- Emissions of harmful substances at tolerable levels, in compliance with the standard [18].

The following was proved to be adequate:

- Accepted design assumptions;

- Developed burner design;

- Developed control system. 
Results of the tests of the prototype burner, with a power of $25 \mathrm{~kW}$

\begin{tabular}{|r|l|c|}
\hline $\begin{array}{r}\text { Item } \\
\text { no. }\end{array}$ & \multicolumn{1}{|c|}{ Test } & Test result / operation \\
\hline 1. & Checking the correctness of operation of the burner elements / systems \\
\hline 1.1. & Pelletized biomass transport system & Correct operation \\
\hline 1.2. & Automatic fuel ignition system & Correct operation \\
\hline 1.3. & $\begin{array}{l}\text { System for stoking the combustion process in the gasifying } \\
\text { chamber }\end{array}$ & Correct operation \\
\hline 1.4. & Automatic grate cleaning system & Correct operation \\
\hline 1.5. & System feeding air to the mixing chamber & Correct operation \\
\hline 2. & Checking of the quality of the combustion process in the burner chambers \\
\hline 2.1. & Burning of pelletized biomass fuels in the gasifying chamber & $\begin{array}{c}\text { High quality of the } \\
\text { combustion process }\end{array}$ \\
\hline 2.2. & $\begin{array}{l}\text { Aftercombustion in the combustion chamber of the gas } \\
\text { mixture created in the mixing chamber }\end{array}$ & $\begin{array}{c}\text { High quality of } \\
\text { Aftercombustion process }\end{array}$ \\
\hline 3. & Measurement of emissions of harmful substances & \multicolumn{2}{|c|}{$50 \mathrm{mg} \cdot \mathrm{m}^{-3}$} \\
\hline 3.1. & Carbon monoxide $(\mathrm{CO})$ & $25 \mathrm{mg} \cdot \mathrm{m}^{-3}$ \\
\hline 3.2. & Particulate matter & \multicolumn{2}{|c|}{} \\
\hline
\end{tabular}

\section{Conclusions}

1. The research and development work was oriented towards designing and developing a modern, innovative burner for central heating boilers.

2. The scope of pre-implementation research and development work covered: development of the burner design, performance of tests of the prototype burner, development of the control system burner automation, as well as preparation and filing of a patent application for the burner.

3. As a result of the conducted research and development work, a modern, innovative burner for central heating boilers was developed ensuring high quality combustion of pelletized biomass fuels.

4. The burner's compact design and overall dimensions allow it to be installed in the majority of solid fuel boilers.

5. When operating with boilers, the designed burner reaches the parameters of combustion class 5 according to the standard PN EN 303-5:2012. The fact that the burner-boiler system meets the criteria of class 5 of this standard is a positive indicator of its efficiency and purity of combustion.

6. Implementation of the designed burner will result in savings on fossil fuels and limited emissions from burning of fossil fuels.

7. To secure the intellectual property rights - industrial property rights, a relevant patent application has been filed. The subject of the invention is a burner for central heating boilers utilizing a renewable energy source [19].

\section{References}

1. Air quality in Europe - 2016 report. EEA Report No 28/2016.

2. EMEP/EEA air pollutant emission inventory. Guidebook 2016. Technical guidance to prepare national emission inventories. EEA Report No 21/2016.

3. Air pollution. Air pollution harms human health and the environment. [online] [17.01.2017]. Available at: http://www.eea.europa.eu/themes/air/intro.

4. How much does industrial air pollution cost Europe? [online] [10.01.2017]. Available at: http://www.eea.europa.eu/articles/how-much-does-industrial-air.

5. Air quality remains a hot topic for many Europeans. [online] [10.01.2017]. Available at: http://www.eea.europa.eu/articles/air-quality-remains-a-hot.

6. Validated monitoring data and air quality maps. [online] [27.01.2017]. Available at: http://www.eea.europa.eu/themes/air/air-quality/map/airbase/airbase. 
7. Air Pollution in World: Real-time Air Quality Index Visual Map. [online] [12.02.2017]. Available at: http://www.aqicn.org/map/world.

8. Reports of the Task Force on Health Aspects of Long-range Transboundary Air Pollution (LRTAP). [online] [12.02.2017]. Available at: http://www.euro.who.int/en/healthtopics/environment-and-health/air-quality/activities/health-aspects-of-long-range-transboundaryair-pollution/reports-of-the-task-force-on-health-aspects-of-long-range-transboundary-airpollution-lrtap.

9. Ambient air pollution: A global assessment of exposure and burden of disease. World Health Organization, 2016. 121 p. [online] [12.02.2017]. Available at:

10. http://www.who.int/phe/publications/air-pollution-global-assessment/en/.

11. Evolution of WHO air quality quidelines: past, present and future (2017). World Health Organization, 2016. 39 p. [online] [12.02.2017]. Available at:

12. http://www.euro.who.int/_data/assets/pdf_file/0019/331660/Evolution-air-quality.pdf?ua=1.

13. European Environment Agency - Policy context. [online] [17.01.2017]. Available at: http://www.eea.europa.eu/themes/air/policy-context.

14. Commission of the European Communities - Communication from the Commission to the Council and the European Parliament. Thematic Strategy on air pollution. Brussels, 21.9.2005 $\operatorname{COM}(2005) 446$ final. [online] [17.01.2017]. Available at: http://eur-lex.europa.eu/legalcontent/EN/TXT/PDF/?uri=CELEX:52005DC0446\&from=EN.

15. Kubica K. Uwarunkowania czystszego spalania paliw stałych w domowych instalacjach produkcji energii cieplnej - Ekspertyza wykonana w ramach projektu FEWE „Doskonalenie poziomu edukacji $\mathrm{w}$ samorządach terytorialnych $\mathrm{w}$ zakresie zrównoważonego gospodarowania energią i ochrony klimatu Ziemi” dzięki wsparciu udzielonemu przez Islandię, Liechtenstein i Norwegię ze środków Mechanizmu Finansowego Europejskiego Obszaru Gospodarczego oraz Norweskiego Mechanizmu Finansowego. (Conditions for cleaner burning of solid fuels in household heat generation systems - Expert opinion within the framework of the FEWE project "Improving the level of education in local self-governments in the scope of sustainable energy management and protecting the Earth's climate" thanks to aid granted by Iceland, Liechtenstein and Norway from funds of the Financial Mechanism of the European Economic Area and Norwegian Financial Mechanism.) Gliwice, 2010, 21 p. (In Polish)

16. O lepszą jakość powietrza. Smog nasz powszedni. Samorząd Miejski nr 10 (234) (For better air quality. Our daily smog. City Self-government No. 10. (234)), grudzień 2016, pp. 10-11. (In Polish).

17. Tak rząd chce walczyć ze smogiem. Inwestycje w piece i lepszy węgiel. [online] [17.01.2017]. (This is how the government wants to fight smog. Investments in burners and better coal.) Available at: http://www.rmf24.pl/fakty/polska/news-tak-rzad-chce-walczyc-ze-smogieminwestycje-w-piece-i-lepszy,nId,2335126 (In Polish).

18. PN-EN 14961 Solid biofuels - Fuel Specification and classes.

19. PN-EN 303-5:2012 Heating boilers - Part 5: Heating boilers for solid fuels, manually and automatically stoked, nominal heat output of up to $500 \mathrm{~kW}$ - Terminology, requirements, testing and marking. (Heating boilers - Part 5: Heating boilers for solid fuels, manually and automatically stoked, nominal heat output of up to $500 \mathrm{~kW}$ - Terminology, requirements, testing and marking).

20. PN-EN 15270:2008 Pellet burners for small heating boilers. Definitions, requirements, testing, marking.

21. Kowalewski A. Pionier Elektryk. Palnik do kotłów c.o. wykorzystujący źródło energii odnawialnej. (Burner for central heating boilers utilizing a renewable energy source). Patent Application nr P.418339, Patent Office of the Republic of Poland, 2016. (In Polish). 